\title{
Perlucidibaca piscinae gen. nov., sp. nov., a freshwater bacterium belonging to the family Moraxellaceae
}

Correspondence Jang-Cheon Cho chojc@inha.ac.kr

\author{
Jaeho Song, Yoe-Jin Choo and Jang-Cheon Cho
}

Division of Biology and Ocean Sciences, Inha University, Incheon 402-751, Republic of Korea

\begin{abstract}
A freshwater bacterium, designated $\mathrm{IMCC} 1704^{\top}$, was isolated from a eutrophic pond. The strain was Gram-negative, oxidase-positive, catalase-negative, chemoheterotrophic and facultatively aerobic with cells that were motile rods with a single polar flagellum. Based on 16S rRNA gene sequence similarity analyses, the novel strain was most closely related to the genera Alkanindiges (91.7\%), Acinetobacter (89.0-91.2\%), Moraxella (87.9-90.1\%), Psychrobacter (87.2-89.5\%) and Enhydrobacter (87.8\%). Phylogenetic trees generated using 16S rRNA gene sequences showed that the novel isolate belonged to the family Moraxellaceae of the class Gammaproteobacteria and formed a distinct phyletic lineage within the family. The DNA G+C content of the strain was $63.1 \mathrm{~mol} \%$ and the predominant constituents of the cellular fatty acids were $\mathrm{C}_{16: 1} \omega 7 c$ and/or iso- $\mathrm{C}_{15: 0} 2-\mathrm{OH}(21.2 \%), \mathrm{C}_{18: 1} \omega 7 c(12.8 \%)$ and $\mathrm{C}_{12: 0} 3-\mathrm{OH}$ (12.3\%). These chemotaxonomic properties, together with several phenotypic characteristics, differentiated the novel strain from other members of the family Moraxellaceae. From the taxonomic data, which revealed the distant relationship of the new strain to the related genera, the strain should be classified as a novel genus and species in the family Moraxellaceae, for which the name Perlucidibaca piscinae gen. nov., sp. nov. is proposed. The type strain of Perlucidibaca piscinae sp. nov. is IMCC $1704^{\top}\left(=\mathrm{KCCM} 42363^{\top}=\operatorname{NBRC} 102354^{\top}\right)$.
\end{abstract}

The family Moraxellaceae of the order Pseudomonadales in the class Gammaproteobacteria was proposed by Rossau et al. (1991) based on comprehensive DNA-rRNA hybridization results. The family currently comprises five recognized genera: Moraxella (Lwoff, 1939), Acinetobacter (Brisou \& Prévot, 1954), Psychrobacter (Juni \& Heym, 1986), Enhydrobacter (Staley et al., 1987) and Alkanindiges (Bogan et al., 2003). Because the members of the family Moraxellaceae are widely distributed in diverse environments and are of clinical importance, many novel species, especially within the genera Acinetobacter and Psychrobacter, have been isolated and classified recently (Bakermans et al., 2006; Bozal et al., 2003; Carr et al., 2003; Jung et al., 2005; Nemec et al., 2001, 2003; Yoon et al., 2005b). The present study focuses on the description of strain $\mathrm{IMCC} 1704^{\mathrm{T}}$ that was isolated from a freshwater pond (Song et al., 2007). Based on the taxonomic data collected in this study, we propose the inclusion of the strain in a new genus and novel species within the family Moraxellaceae.

The GenBank/EMBL/DDBJ accession number for the 16S rRNA gene sequence of strain IMCC $1704^{\top}$ is DQ664237.

An electron micrograph of a cell of strain IMCC $1704^{\top}$ is available with the online version of this paper.
Strain IMCC $1704^{\mathrm{T}}$ was isolated from an artificial freshwater pond located inside Inha University, Korea, by a standard dilution plating method on R2A agar (Reasoner \& Geldreich, 1985; Difco) plates. After incubating the agar plates aerobically at $20{ }^{\circ} \mathrm{C}$ for 5 days, strain IMCC $1704^{\mathrm{T}}$ was purified as single colonies and subsequently stored at $-80{ }^{\circ} \mathrm{C}$ as $10 \%(\mathrm{v} / \mathrm{v})$ glycerol suspensions. After the optimum growth temperature of the strain was determined, cultures were routinely maintained on R2A agar at $30{ }^{\circ} \mathrm{C}$.

DNA extraction, PCR and sequencing of the 16S rRNA gene were performed as described previously (Cho \& Giovannoni, 2003) and almost complete 16S rRNA gene sequences $(1467 \mathrm{bp})$ of strain IMCC $1704^{\mathrm{T}}$ were obtained. Preliminary sequence comparisons with 16S rRNA gene sequences held in the GenBank database showed that the novel strain belonged to the family Moraxellaceae in the class Gammaproteobacteria. The 16S rRNA gene sequences of the novel strain were aligned using the ARB software package (Ludwig et al., 2004) and 1269 unambiguously aligned nucleotide positions were used for phylogenetic analyses in PAUP 4.0 beta 10 (Swofford, 2002). Phylogenetic trees were generated by the neighbour-joining (Saitou \& Nei, 1987) method with Jukes-Cantor distance (Jukes \& Cantor, 1969), maximum-parsimony (Fitch, 1971) and 
maximum-likelihood (Felsenstein, 1981) algorithms. The resultant neighbour-joining and maximum-parsimony trees were evaluated by bootstrap analysis based on 1000 resamplings.

Sequence comparisons based on the multiple alignment in the ARB database, Ribosomal Database Project (RDP-II) and BLASTN search results showed that the most closely related cultured species with respect to strain $\mathrm{IMCC} 1704^{\mathrm{T}}$ was 'Alkanindiges hongkongensis' HKU9 (92.5\% gene sequence similarity), which was described by Woo et al. (2005) but the name has not yet been validly published. Strain IMCC1704 ${ }^{\mathrm{T}}$ showed the highest 16S rRNA gene sequence similarity with the recognized species Alkanindiges illinoisensis DSM $15370^{\mathrm{T}}$ $(91.7 \%)$, followed by Acinetobacter calcoaceticus ATCC $23055^{\mathrm{T}}(91.2 \%)$ and Acinetobacter parvus LMG $21765^{\mathrm{T}}$ $(91.0 \%)$. Strain IMCC $1704^{\mathrm{T}}$ was moderately related to the genera of the family Moraxellaceae with relatively low $16 \mathrm{~S}$ rRNA gene sequence similarities: Alkanindiges, 91.7\%; Acinetobacter, 89.0-91.2\%; Moraxella, 87.9-90.1\%; Psychrobacter, 87.2-89.5\% and Enhydrobacter, $87.8 \%$. No other recognized species exceeded $92.0 \% 16 \mathrm{~S}$ rRNA gene sequence similarity to strain IMCC $1704^{\mathrm{T}}$. In all of the phylogenetic trees generated in this study, strain IMCC $1704^{\mathrm{T}}$, the uncultured freshwater bacteria $156 \mathrm{ds} 20$ (GenBank accession no. AY212607; Simpson et al., 2004) and 216ds20 (AY212663; Simpson et al., 2004) formed an independent monophyletic lineage with $96-100 \%$ bootstrap support for a position within the family Moraxellaceae (Fig. 1). This lineage formed a larger clade with the genera Acinetobacter and Alkanindiges in all of the phylogenetic trees; however, the phylogenetic relationship between strain IMCC $1704^{\mathrm{T}}$ and the genera Acinetobacter and Alkanindiges was distinct. The results of phylogenetic analyses revealed that strain IMCC $1704^{\mathrm{T}}$ could not be associated with any of the known genera in the family. Therefore, strain IMCC $1704^{\mathrm{T}}$ was considered to represent a new genus in the family Moraxellaceae.
For phenotypic characterizations, strain $\mathrm{IMCC} 1704^{\mathrm{T}}$ was routinely grown on $\mathrm{R} 2 \mathrm{~A}$ agar at $30{ }^{\circ} \mathrm{C}$, unless otherwise specified. The type species of the most closely related genera Acinetobacter and Alkanindiges were also phenotypically characterized. Alkanindiges illinoisensis DSM $15370^{\mathrm{T}}$ and Acinetobacter calcoaceticus ATCC $23055^{\mathrm{T}}$ were purchased from the Deutsche Sammlung von Mikroorganismen und Zellkulturen (DSMZ) collection and the Korean Culture and Type Collection (KCTC), respectively. Both type strains obtained from the culture collections were grown on R2A agar at $25{ }^{\circ} \mathrm{C}$, unless otherwise indicated. Cell morphology and size were examined by transmission electron microscopy (CM200; Philips) and phase-contrast microscopy (80i; Nikon) using a 3 day culture. For electron microscopy, cells were washed twice with sodium cacodylate buffer and negatively stained with $2 \%$ phosphotungstic acid ( $\mathrm{pH} 7.0-7.2$ ) on Formvarcoated copper grids. Colony morphology, size and colour were examined from cultures grown aerobically for 5 days. Motility based on flagella was tested from wet mounts using a 3 day culture. The growth temperature range and optimum were tested on R2A agar at 4, 10, 15, 20, 25, 30, 37 and $42{ }^{\circ} \mathrm{C}$. The $\mathrm{pH}$ range and optimum were examined on $\mathrm{R} 2 \mathrm{~A}$ at $\mathrm{pH}$ values from $\mathrm{pH} 4.0$ to 12.0 (at intervals of $1.0 \mathrm{pH}$ units), adjusted with $0.1 \mathrm{M} \mathrm{HCl}$ and $0.1 \mathrm{M} \mathrm{NaOH}$. The optimum $\mathrm{NaCl}$ concentration for growth was determined on R2A agar supplemented with $0-15 \%$ $\mathrm{NaCl}$ (at intervals of $0.5 \%$ from $0-5.0 \%, 7.5 \%, 10.0 \%$, $12.5 \%$ and $15.0 \%, \mathrm{w} / \mathrm{v})$. The ranges and optima of temperature, $\mathrm{pH}$ and $\mathrm{NaCl}$ concentration for growth were monitored for 2 weeks. Anaerobic growth was tested using both the MGC anaerobic system (Mitsubishi Gas Chemical company, Inc.) and the Anaerocult $\mathrm{C}$ mini (EM Science). The catalase test was performed by the addition of $3.0 \%$ hydrogen peroxide to fresh colonies and oxidase activity was determined using Kovacs' solution (Kovacs, 1956). Other biochemical tests were carried out with API 20NE

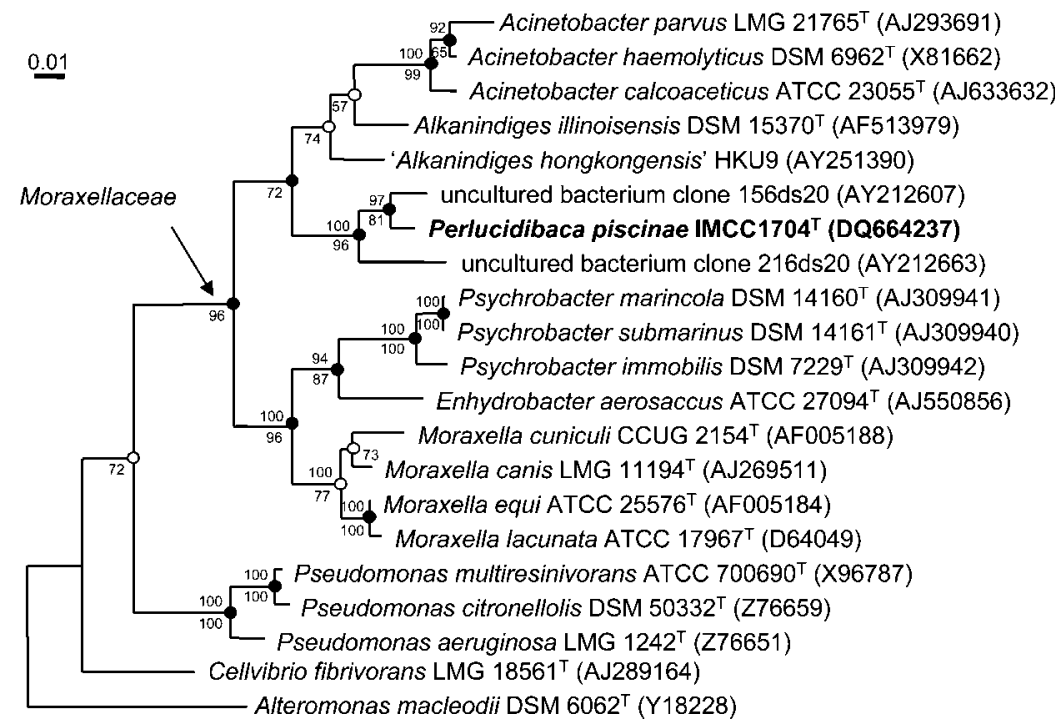

Fig. 1. Neighbour-joining phylogenetic tree, based on 16S rRNA gene sequences, showing relationships between strain IMCC $1704^{\top}$ and representatives of the family Moraxellaceae. Bootstrap percentages (above $50 \%$ ) from both neighbour-joining (above nodes) and maximum-parsimony (below nodes) are shown. The closed and open circles at each node indicate nodes recovered reproducibly by all treeing methods or by two treeing methods, respectively. Bar, 0.01 substitutions per nucleotide position. 
Table 1. Characteristics that differentiate strain $\mathrm{IMC} 1704^{\top}$ from the genera of the family Moraxellaceae

Taxa: 1, strain IMCC1704 ${ }^{\mathrm{T}}$; 2, Acinetobacter ( $n=17$, data taken collectively from this study and Bouvet \& Grimont, 1986; Carr et al., 2003; Juni \& Bøvre, 2005; Nemec et al., 2001, 2003; Nishmura et al., 1988); 3, Alkanindiges ( $n=1$, data from this study and Bogan et al., 2003); 4, Psychrobacter ( $n=27$, data taken collectively from Bakermans et al., 2006; Heuchert et al., 2004; Jung et al., 2005; Juni \& Bøvre, 2005; Romanenko et al., 2004; Yoon et al., 2005a, b); 5, Enhydrobacter ( $n=1$, Staley et al., 1987); 6, Moraxella ( $n=17$, data taken collectively from Angelos et al., 2007; Juni \& Bøvre, 2005; Kodjo et al., 1995; Vandamme et al., 1993; Xie \& Yokota, 2005). +, Present in $90 \%$ or more of the species; -, absent in $90 \%$ or more of the species; $\mathrm{v}$, present in $11-89 \%$ of the species, ND, no data available; w, weakly positive.

\begin{tabular}{|c|c|c|c|c|c|c|}
\hline Characteristic & 1 & 2 & 3 & 4 & 5 & 6 \\
\hline Growth at $37^{\circ} \mathrm{C}$ & + & + & + & $\mathrm{V}$ & + & + \\
\hline Oxidase & + & - & $-\ddagger$ & + & + & + \\
\hline Catalase & - & $+\dagger$ & $+\ddagger$ & + & + & + \\
\hline Acid production from glucose & - & $\mathrm{V}$ & $-\ddagger$ & + & $\mathrm{ND}$ & - \\
\hline Major quinone & Q-8 & Q-8‡, Q-9\$ & Q-8末 & Q-8 & $\mathrm{ND}$ & Q-8II \\
\hline DNA G $+C$ content $(\mathrm{mol} \%)$ & 63.1 & $40-46$ & $46.2 \neq$ & $42-50$ & 66 & $40-49.6$ \\
\hline
\end{tabular}

${ }^{\star}$ Data for Acinetobacter calcoaceticus, Acinetobacter schindleri and Acinetobacter ursingii.

$\dagger$ Data for M. boevrei, M. lacunata and M. lincolnii.

¥Data obtained from this study for Acinetobacter calcoaceticus ATCC $23055^{\mathrm{T}}$ or Alkanindiges illinoisensis DSM $15370^{\mathrm{T}}$.

$\S$ Data for Acinetobacter radioresistens.

IIData for M. oblonga.

Table 2. Biochemical characteristics and carbon source utilization patterns that differentiate strains IMCC1704 ${ }^{\top}$, Acinetobacter calcoaceticus ATCC $23055^{\top}$ and Alkanindiges illinoisensis DSM $15370^{\top}$

Strains: 1, IMCC $1704^{\mathrm{T}}$; 2, Acinetobacter calcoaceticus ATCC $23055^{\mathrm{T}} ; 3$, Alkanindiges illinoisensis DSM $15370^{\mathrm{T}}$. + , Positive; - , negative; w, weakly positive. All data were obtained in the present study. All the strains were negative for acid production from glucose, for activities of arginine dihydrolase, trypsin, $\alpha$-chymotrypsin, acid phosphatase, $\alpha$-galactosidase, $\beta$-galactosidase, $\beta$-glucuronidase, $\alpha$-glucosidase, $\beta$-glucosidase, $N$-acetyl- $\beta$ glucosaminidase, $\alpha$-mannosidase and $\alpha$-fucosidase and for utilization of methanol, ethanol, DL-glyceraldehyde, D-cellobiose, D-lactose, melibiose, Dmelezitose, adonitol, succinic acid, L-glutamic acid and L-leucine. All the strains were positive for esterase (C4) and esterase lipase (C8) activities and for utilization of L-proline and were weakly positive for aesculin hydrolysis.

\begin{tabular}{|c|c|c|c|}
\hline Characteristic & 1 & 2 & 3 \\
\hline \multicolumn{4}{|l|}{ API 20NE } \\
\hline Nitrate reduction & $\mathrm{W}$ & + & + \\
\hline Gelatin liquefaction & - & - & $\mathrm{w}$ \\
\hline Urease activity & - & + & + \\
\hline \multicolumn{4}{|l|}{ API ZYM } \\
\hline Lipase (C14) & - & + & + \\
\hline Leucine arylamidase & - & + & - \\
\hline Valine arylamidase & - & + & - \\
\hline Cystine arylamidase & - & + & - \\
\hline Naphthol-AS-BI-phosphohydrolase & - & + & + \\
\hline \multicolumn{4}{|l|}{ Carbon source utilization } \\
\hline Glycerol, gluconic acid, itaconic acid, & + & - & + \\
\hline D-Fructose, glucuronic acid, L-alanine & - & + & - \\
\hline Propionic acid & - & + & + \\
\hline
\end{tabular}


and API ZYM (bioMérieux) kits following the manufacturer's instructions. Sole carbon source utilization tests were performed using custom-made 48-well microplates containing 47 different carbon compounds at a final concentration of $0.2 \%(\mathrm{w} / \mathrm{v}$ or $\mathrm{v} / \mathrm{v})$, according to Choo et al. (2007) except that microplates were inoculated with bacterial suspensions in phosphate-buffered saline ( $\mathrm{pH}$ 7.4). Cells at the exponential growth phase were harvested and cell densities were adjusted to approximately $2 \times 10^{3}$ cells $\mathrm{ml}^{-1}$ in phosphate-buffered saline ( $\mathrm{pH}$ 7.4). A $1 \mathrm{ml}$ sample of cell suspension was inoculated per well and the microplates were incubated at $30{ }^{\circ} \mathrm{C}$ for strain IMCC $1704^{\mathrm{T}}$ and $25^{\circ} \mathrm{C}$ for strains DSM $15370^{\mathrm{T}}$ and ATCC $23055^{\mathrm{T}}$. After incubation of the microplates for 1 week, cellular growth and purity were checked by DAPI-stained epifluorescence microscopy. The DNA G + C content (Mesbah et al., 1989) was analysed by using HPLC with a Discovery C18 column ( $5 \mu \mathrm{m}, 15 \mathrm{~cm} \times 4.6 \mathrm{~mm}$; Supelco). Cellular fatty acid methyl esters of strains IMCC1704 ${ }^{\mathrm{T}}$, DSM $15370^{\mathrm{T}}$ and ATCC $23055^{\mathrm{T}}$ were prepared from the cultures grown on $\mathrm{R} 2 \mathrm{~A}$ agar at $30{ }^{\circ} \mathrm{C}$ for 3 days and were analysed according to the instructions of the Microbial Identification System (MIDI) by the Korean Culture Center of Microorganisms (KCCM). Respiratory quinones were analysed using a reverse-phase HPLC (Komagata \& Suzuki, 1987).

Strain IMCC $1704^{\mathrm{T}}$ was Gram-negative, chemoheterotrophic, facultatively aerobic, catalase-negative and oxidase-positive. Cells were motile short-rods that had a single polar flagellum (see Supplementary Figure S1 in IJSEM online). Detailed results of the phenotypic and biochemical tests are given in the species description and in Tables 1, 2 and 3. Strain IMCC $1704^{\mathrm{T}}$ could be differentiated from the other genera of the family Moraxellaceae by several phenotypic characteristics and the DNA G $+\mathrm{C}$ content (Table 1). The DNA G + C content of strain IMCC1704 ${ }^{\mathrm{T}}$ was $63.1 \mathrm{~mol} \%$, which was $13-23 \mathrm{~mol} \%$ higher than that of other members of the family Moraxellaceae, except for Enhydrobacter aerosaccus. The biochemical characteristics and carbon source utilization patterns also clearly differentiated strain IMCC $1704^{\mathrm{T}}$ from the type strains of the type species of the genera Alkanindiges and Acinetobacter (Table 2). The major fatty acid constituents of strain

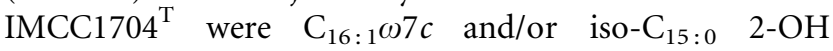
$(21.2 \%), \mathrm{C}_{18: 1} \omega 7 c(12.8 \%), \mathrm{C}_{12: 0} 3-\mathrm{OH}(12.3 \%), \mathrm{C}_{12: 0}$ $(10.1 \%)$ and $\mathrm{C}_{18: 1} \omega 9 c(9.2 \%)$, and they were different from those of Alkanindiges illinoisensis DSM $15370^{\mathrm{T}}$ and Acinetobacter calcoaceticus ATCC $23055^{\mathrm{T}}$.

It is evident from the low $16 \mathrm{~S}$ rRNA gene sequence similarity $(<92 \%)$, the formation of an independent phyletic line in the phylogenetic analyses (Fig. 1) and the differential phenotypic characteristics (Tables 1, 2 and 3) that strain IMCC $1704^{\mathrm{T}}$ cannot be assigned to any of the known genera in the family Moraxellaceae. Conclusively, based on the taxonomic results in this study, strain IMCC $1704^{\mathrm{T}}$ should be classified as a novel species within a new genus, for which the name Perlucidibaca piscinae gen. nov., sp. nov. is proposed.

\section{Description of Perlucidibaca gen. nov.}

Perlucidibaca (Per.lu.ci.di.ba'ca. L. adj. perlucidus transparent, pellucid; L. fem. n. baca a small round fruit, a berry; N.L. fem. n. Perlucidibaca a transparent berry).

Gram-negative. Oxidase-positive and catalase-negative. Chemoheterotrophic and facultatively aerobic. Anaerobic growth is similar to aerobic growth. Cells are short rods that are motile by a polar flagellum. Indole is produced. Nitrate reduction is weakly positive. Acid is not produced from glucose fermentation. Predominant cellular fatty acids are $\mathrm{C}_{16: 1} \omega 7 c$ and/or iso- $\mathrm{C}_{15: 0} 2-\mathrm{OH}, \mathrm{C}_{18: 1} \omega 7 c$, $\mathrm{C}_{12: 0} 3-\mathrm{OH}$ and $\mathrm{C}_{12: 0}$. The DNA $\mathrm{G}+\mathrm{C}$ content is $63.1 \mathrm{~mol} \%$. The major respiratory quinone is Q-8. Phylogenetically, the genus belongs to the family Moraxellaceae. The type species is Perlucidibaca piscinae.

\section{Description of Perlucidibaca piscinae sp. nov.}

Perlucidibaca piscinae (pis.ci'nae. L. gen. n. piscinae of a fish-pond).

The description is the same as that for the genus, with the following additional properties. Cells in the exponential phase are short rods, $0.7-1.2 \mu \mathrm{m}$ long and $0.5-0.7 \mu \mathrm{m}$ wide. Colonies on R2A agar are circular, convex, smooth, butyrous and transparent with an entire margin. Colony

Table 3. Cellular fatty acid content (\%) of strain IMCC1704 ${ }^{\top}$, Acinetobacter calcoaceticus ATCC $23055^{\top}$ and Alkanindiges illinoisensis DSM $15370^{\top}$

Strains: 1, IMCC $1704^{\mathrm{T}}$; 2, Acinetobacter calcoaceticus ATCC $23055^{\mathrm{T}}$; 3 , Alkanindiges illinoisensis DSM $15370^{\mathrm{T}}$. - , Not detected. All the strains were grown on $\mathrm{R} 2 \mathrm{~A}$ agar at $30{ }^{\circ} \mathrm{C}$ for 3 days. Only fatty acids representing at least $1 \%$ of the total cellular fatty acids of at least one of the strains are shown.

\begin{tabular}{|lrcc|}
\hline Fatty acid & $\mathbf{1}$ & $\mathbf{2}$ & $\mathbf{3}$ \\
\hline $\mathrm{C}_{10: 0}$ & 3.4 & 0.2 & 4.9 \\
$\mathrm{C}_{12: 0}$ & 10.1 & 5.5 & 3.6 \\
$\mathrm{C}_{14: 0}$ & 3.1 & 0.9 & 1.9 \\
$\mathrm{C}_{15: 0}$ & 0.5 & 1.3 & 0.6 \\
$\mathrm{C}_{16: 0}$ & 5.8 & 14.7 & 16.9 \\
$\mathrm{C}_{17: 0}$ & 0.7 & 3.4 & - \\
$\mathrm{C}_{18: 0}$ & 2.7 & 1.7 & 0.9 \\
$\mathrm{C}_{16: 1} \omega 7 c$ and/or iso- $\mathrm{C}_{15: 0} 2-\mathrm{OH}$ & 21.2 & 20.4 & 42.7 \\
$\mathrm{C}_{17: 1} \omega 8 c$ & 5.5 & 5.6 & 1.1 \\
$\mathrm{C}_{18: 1} \omega 7 c$ & 12.8 & 2.0 & 0.6 \\
$\mathrm{C}_{18: 1} \omega 9 c$ & 9.2 & 28.9 & 10.3 \\
$\mathrm{C}_{18: 2} \omega 6,9 c$ and/or anteiso- $\mathrm{C}_{18: 0}$ & - & - & 1.3 \\
$\mathrm{C}_{10: 0} 2-\mathrm{OH}$ & 1.5 & - & 1.7 \\
$\mathrm{C}_{10: 0} 3-\mathrm{OH}$ & 0.6 & - & 1.3 \\
$\mathrm{C}_{12: 0} 2-\mathrm{OH}$ & 0.4 & 2.7 & 1.0 \\
$\mathrm{C}_{12: 0} 3-\mathrm{OH}$ & 12.3 & 5.3 & 9.6 \\
iso-C & 0.9 & 1.1 & - \\
Unknown peak 12.488 & 1.4 & 0.6 & 0.8 \\
Unknown peak 10.928 & - & 3.0 & - \\
\hline
\end{tabular}


size is $0.5-1.0 \mathrm{~mm}$ after incubation on $\mathrm{R} 2 \mathrm{~A}$ at $30{ }^{\circ} \mathrm{C}$ for 5 days. Grows at $8-37{ }^{\circ} \mathrm{C}$ (optimally at $30{ }^{\circ} \mathrm{C}$ ), but not at 4 and $42{ }^{\circ} \mathrm{C}$. Growth occurs at $\mathrm{pH} 6-10$ and with $0-1 \%$ $\mathrm{NaCl}$; optimum at $\mathrm{pH} 7.0$ and without $\mathrm{NaCl}$. Biochemical characteristics and carbon source utilization patterns are shown in Table 2 . The cellular fatty acid content is listed in Table 3.

The type strain, IMCC $1704^{\mathrm{T}}\left(=\mathrm{KCCM} 42363^{\mathrm{T}}=\mathrm{NBRC}\right.$ $102354^{\mathrm{T}}$ ), was isolated from an artificial freshwater pond located inside Inha University, Korea.

\section{Acknowledgements}

We are grateful to Dr Jean Euzéby for his recommendations about etymology. This study was supported by Inha University Research Grant.

\section{References}

Angelos, J. A., Spinks, P. Q., Ball, L. M. \& George, L. W. (2007). Moraxella bovoculi sp. nov., isolated from calves with infectious bovine keratoconjunctivitis. Int J Syst Evol Microbiol 57, 789-795.

Bakermans, C., Ayala-del-Rio, H. L., Ponder, M. A., Vishnivetskaya, T., Gilichinsky, D., Thomashow, M. F. \& Tiedje, J. M. (2006). Psychrobacter cryohalolentis sp. nov. and Psychrobacter arcticus sp. nov., isolated from Siberian permafrost. Int J Syst Evol Microbiol 56, 1285-1291.

Bogan, B. W., Sullivan, W. R., Kayser, K. J., Derr, K. D., Aldrich, H. C. \& Paterek, J. R. (2003). Alkanindiges illinoisensis gen. nov., sp. nov., an obligately hydrocarbonoclastic, aerobic squalane-degrading bacterium isolated from oilfield soils. Int J Syst Evol Microbiol 53, 1389-1395.

Bouvet, P. J. M. \& Grimont, P. A. D. (1986). Taxonomy of the genus Acinetobacter with the recognition of Acinetobacter baumannii sp. nov., Acinetobacter haemolyticus sp. nov., Acinetobacter johnsonii sp. nov., and Acinetobacer junii sp. nov. and emended descriptions of Acinetobacter calcoaceticus and Acinetobacter lwoffii. Int J Syst Bacteriol 36, 228-240.

Bozal, N., Montes, M. J., Tudela, E. \& Guinea, J. (2003). Characterization of several Psychrobacter strains isolated from Antarctic environments and description of Psychrobacter luti sp. nov. and Psychrobacter fozii sp. nov. Int J Syst Evol Microbiol 53, 1093-1100.

Brisou, J. \& Prévot, A. R. (1954). Études de systématique bactérienne. $\mathrm{X}$. Révision des espèces réunies dans le genre Achromobacter. Ann Inst Pasteur (Paris) 86, 722-728.

Carr, E. L., Kämpfer, P., Patel, B. K., Gurtler, V. \& Seviour, R. J. (2003). Seven novel species of Acinetobacter isolated from activated sludge. Int J Syst Evol Microbiol 53, 953-963.

Cho, J.-C. \& Giovannoni, S. J. (2003). Parvularcula bermudensis gen. nov., sp. nov., a marine bacterium that forms a deep branch in the $\alpha$ Proteobacteria. Int J Syst Evol Microbiol 53, 1031-1036.

Choo, Y. J., Lee, K., Song, J. \& Cho, J. C. (2007). Puniceicoccus vermicola gen. nov., sp. nov., a novel marine bacterium, and description of Puniceicoccaceae fam. nov., Puniceicoccales ord. nov., Opitutaceae fam. nov., Opitutales ord. nov. and Opitutae classis nov. in the phylum 'Verrucomicrobia'. Int J Syst Evol Microbiol 57, 532-537.

Felsenstein, J. (1981). Evolutionary trees from DNA sequences: a maximum likelihood approach. J Mol Evol 17, 368-376.

Fitch, W. M. (1971). Toward defining the course of evolution: minimum change for a specific tree topology. Syst Zool 20, 406-416.
Heuchert, A., Glockner, F. O., Amann, R. \& Fischer, U. (2004). Psychrobacter nivimaris sp. nov., a heterotrophic bacterium attached to organic particles isolated from the South Atlantic (Antarctica). Syst Appl Microbiol 27, 399-406.

Jukes, T. H. \& Cantor, C. R. (1969). Evolution of protein molecules. In Mammalian Protein Metabolism, pp. 21-132. Edited by H. N. Munro. New York.

Jung, S. Y., Lee, M. H., Oh, T. K., Park, Y. H. \& Yoon, J. H. (2005). Psychrobacter cibarius sp. nov., isolated from jeotgal, a traditional Korean fermented seafood. Int J Syst Evol Microbiol 55, 577-582.

Juni, E. \& Bøvre, K. (2005). Family II. Moraxellaceae Rossau, Van Landschoot, Gillis and De Ley 1991. 317 ${ }^{\mathrm{VP}}$. In Bergey's Manual of Systematic Bacteriology, 2nd edn, vol 2 (The Proteobacteria), part B (The Gammaproteobacteria), pp. 411-441. Edited by D. J. Brenner, N. R. Krieg, J. T. Staley \& G. M. Garrity. New York: Springer.

Juni, E. \& Heym, G. A. (1986). Psychrobacter immobilis gen. nov., sp. nov.: genospecies composed of gram-negative, aerobic, oxidasepositive coccobacilli. Int J Syst Bacteriol 36, 388-391.

Kodjo, A., Tonjum, T., Richard, Y. \& Bovre, K. (1995). Moraxella caprae sp. nov., a new member of the classical Moraxellae with very close affinity to Moraxella bovis. Int J Syst Bacteriol 45, $467-471$.

Komagata, K. \& Suzuki, K. (1987). Lipids and cell-wall analysis in bacterial systematics. Methods Microbiol 19, 161-207.

Kovacs, N. (1956). Identification of Pseudomonas pyocyanea by the oxidase reaction. Nature 178, 703.

Ludwig, W., Strunk, O., Westram, R., Richter, L., Meier, H., Yadhukumar, Buchner, A., Lai, T., Steppi, S. \& other authors (2004). ARB: a software environment for sequence data. Nucleic Acids Res 32, 1363-1371.

Lwoff, A. (1939). Révision et démembrement des Hemophileae, le genre Moraxella nov. gen. Ann Inst Pasteur (Paris) 62, 168-176.

Mesbah, M., Premachandran, U. \& Whitman, W. B. (1989). Precise measurement of the $\mathrm{G}+\mathrm{C}$ content of deoxyribonucleic acid by highperformance liquid chromatography. Int J Syst Bacteriol 39, 159-167.

Nemec, A., De Baere, T., Tjernberg, I., Vaneechoutte, M., van der Reijden, T. J. \& Dijkshoorn, L. (2001). Acinetobacter ursingii sp. nov. and Acinetobacter schindleri sp. nov., isolated from human clinical specimens. Int J Syst Evol Microbiol 51, 1891-1899.

Nemec, A., Dijkshoorn, L., Cleenwerck, I., De Baere, T., Janssens, D., Van Der Reijden, T. J., Jezek, P. \& Vaneechoutte, M. (2003). Acinetobacter parvus sp. nov., a small-colony-forming species isolated from human clinical specimens. Int J Syst Evol Microbiol 53, 1563-1567.

Nishmura, Y., Ino, T. \& Ilzuka, H. (1988). Acinetobacter radioresistens sp. nov. isolated from cotton and soil. Int J Syst Bacteriol 38, 209-211.

Reasoner, D. J. \& Geldreich, E. E. (1985). A new medium for the enumeration and subculture of bacteria from potable water. Appl Environ Microbiol 49, 1-7.

Romanenko, L. A., Lysenko, A. M., Rohde, M., Mikhailov, V. V. \& Stackebrandt, E. (2004). Psychrobacter maritimus sp. nov. and Psychrobacter arenosus sp. nov., isolated from coastal sea ice and sediments of the Sea of Japan. Int J Syst Evol Microbiol 54, 1741-1745.

Rossau, R., Van Landschoot, A., Gillis, M. \& De Ley, J. (1991). Taxonomy of Moraxellaceae fam. nov., a new bacterial family to accommodate the genera Moraxella, Acinetobacter, and Psychrobacter and related organisms. Int J Syst Bacteriol 41, 310-319.

Saitou, N. \& Nei, M. (1987). The neighbor-joining method: a new method for reconstructing phylogenetic trees. Mol Biol Evol 4, $406-425$. 
Simpson, J. M., Santo Domingo, J. W. \& Reasoner, D. J. (2004). Assessment of equine fecal contamination: the search for alternative bacterial source-tracking targets. FEMS Microbiol Ecol 47, 65-75.

Song, J., Yang, S.-J. \& Cho, J.-C. (2007). "Bring to lab" of 19 novel species among 60 isolates retrieved from a freshwater pond. $J$ Microbiol Biotechnol 17, 168-175.

Staley, J. T., Irgens, R. L. \& Brenner, D. J. (1987). Enhydrobacter aerosaccus gen. nov., sp. nov., a gas-vacuolated, facultatively anaerobic, heterotrophic rod. Int J Syst Bacteriol 37, 289-291.

Swofford, D. (2002). PAUP*: Phylogenetic analysis using parsimony (*and other methods). Sunderland, MA: Sinauer Associates.

Vandamme, P., Gillis, M., Vancanneyt, M., Hoste, B., Kersters, K. \& Falsen, E. (1993). Moraxella lincolnii sp. nov., isolated from the human respiratory tract, and reevaluation of the taxonomic position of Moraxella osloensis. Int J Syst Bacteriol 43, 474-481.
Woo, P. C., Tse, H., Lau, S. K., Leung, K. W., Woo, G. K., Wong, M. K., Ho, C. M. \& Yuen, K. Y. (2005). Alkanindiges hongkongensis sp. nov. A novel Alkanindiges species isolated from a patient with parotid abscess. Syst Appl Microbiol 28, 316-322.

Xie, C. H. \& Yokota, A. (2005). Transfer of the misnamed [Alysiella] sp. IAM 14971 (=ATCC 29468) to the genus Moraxella as Moraxella oblonga sp. nov. Int $J$ Syst Evol Microbiol 55, 331-334.

Yoon, J. H., Lee, C. H., Kang, S. J. \& Oh, T. K. (2005a). Psychrobacter celer sp. nov., isolated from sea water of the South Sea in Korea. Int $J$ Syst Evol Microbiol 55, 1885-1890.

Yoon, J. H., Lee, C. H., Yeo, S. H. \& Oh, T. K. (2005b). Psychrobacter aquimaris sp. nov. and Psychrobacter namhaensis sp. nov., isolated from sea water of the South Sea in Korea. Int J Syst Evol Microbiol 55, 1007-1013. 